\title{
An Empirical Analysis of Trade Support System and Export Performance in Korean SMEs
}

\author{
Byoung-Goo KIM \\ Associate Professor, Division of Global Business, Hanshin University, Korea \\ E-mail: bgkim@hs.ac.kr
}

Received: February 23, 2020. Revised: March 26, 2020. Accepted: March 31, 2020.

\begin{abstract}
Purpose - This study investigates factors that affected the utilization of trade support policies and further analyzed how the utilization of trade support policies affected export performance.

Research design, data, and methodology - With a sample of 223 small and medium-sized export firms from South Korea, this study examines the determinants of the utilization level of trade support system such as export market orientation, learning orientation, network capability and environmental uncertainty by regression analysis. Results - Export market orientation have a positive effect on the utilization of the trade support system and there is positive relationship between learning orientation and the utilization of trade support system. And network capabilities have had a positive impact on the utilization of the trade support system but there is no relationship between environmental uncertainty and the utilization of trade support system. The utilization of the trade support system had a positive effect on export performance.

Conclusions - The internal and external factors of the organization have affected small and medium-sized export firms use of trade support systems. The utilization of trade support system can enhance positive export performance by providing valuable information and resource to external knowledge and also to complementary resources from the external partners.
\end{abstract}

Keywords: Export Market Orientation, Learning Orientation, Network Capability, Trade Support System, Export Performance.

JEL Classification Code: F10, F23.

\section{Introduction}

Although the Korean government, local governments, and trade support agencies are making various policy and institutional efforts to ensure continued growth of small and medium-sized enterprises through the development of overseas markets, their effectiveness is low, and the related systems are required to be readjusted. The reason for the growing interest in export support policies among small and medium-sized enterprises is that there is a limit to relying solely on the domestic market and the scope of their activities should be expanded to overseas markets in order for small and medium-sized enterprises to continue to grow.

While the willingness to increase the global capabilities of small and medium-sized enterprises themselves will be paramount, a new paradigm shift is also urgently needed in the government's support policy for small and medium-sized enterprises to effectively overcome various challenges, such as the recent global economic recession and the expansion of uncertainty. Currently, there are more than 1,000 government-level SME support policies in Korea, but there are no demand-oriented services available, and the imbalance between large and small businesses 
remains a difficult task to solve. Therefore, systematic consideration should be needed to various export support projects being implemented by the Korea International Trade Association, KOTRA, the Ministry of SMEs and Startups, the Korea SMEs and Startup Agency, and local governments in each city and province.

Currently, organizations related to SME export support include government agencies such as the Ministry of Trade, Industry and Energy and the Ministry of SMEs and Startups, and include public institution such as KOTRA, the Korea SMEs and Startup Agency, the Korea Trade Insurance Corporation, the Korea Credit Guarntee Fund, and the Korea Technology Finance Corporation. There are trade support agencies, including the Korea Federation of SMEs and Korea Chamber of Commerce and Industry. In addition, various export support agencies under local governments are either entrusted by the government or are implementing export support policies for small businesses on their own budget.

The importance of SMEs is increasingly emphasized in terms of changes from the existing export structure centered on large companies to small and medium-sized enterprises, namely innovation in the virtuous export structure, job creation and qualitative growth. The export system focused on large companies has been an efficient way to achieve economic growth in Korea until now, but the development of an export ecosystem centered on small and medium-sized enterprises is a very important issue in the future as it has limitations in coping with the rapidly changing external environment.

For the effectiveness of export support policies for small and medium-sized enterprises, proactive intervention, which faithfully reflects SMBs' positions and perspectives, from the stage of policy design, is more effective than follow-up support. Therefore, the export support policy for small businesses should develop into a support method tailored to small businesses in advance rather than follow-up management for companies that have finished their support. However, while research on export support policies for small businesses has been focused on the recognition and utilization of export support projects, research on the impact of the use of export support policies on export performance is insufficient.

Domestic research on export support policies for small businesses can be divided into the impact of characteristics of small businesses on export performance, recognition and utilization of export support policies for small businesses, export support policies and export performance, and research on problems and ways to improve export support policies. However, most of the prior studies have been conducted independently of each subject. Therefore, in this study, the following studies are more integrated. First, what factors promote the use of trade support systems? Second, how does the level of use of the trade support system affect export performance?

In Chapter 2, literature research and hypothesis setting, in Chapter 3, research methodology, and analysis results in Chapter 4, conclusions and implications will be presented in Chapter 5.

\section{Theoretical Background and Hypothesis}

\subsection{Definition and Status of Trade Support System}

Trade support system refers to a system implemented by government agencies or related trade agencies to support exporters who have difficulty in exploring overseas markets even after producing new products due to a lack of marketing capabilities and a lack of specialized export sales personnel (Yoo, 2010). In general, export support systems for small and medium-sized enterprises consist of export activity support systems and overseas market development systems, and are also distinguished as information knowledge support for basic export activities, seminars, and experiential knowledge support such as participation in overseas exhibitions and dispatch of overseas market development teams, depending on the intention of export support systems.

The types of trade or export support systems were set up in accordance with the regulations on the establishment and operation of export support centers for small and medium-sized enterprises, and various types of support systems for overseas marketing of small and medium-sized exporters, including financial services, sales channels and education by setting up offices in the capital region and provincial areas.

First of all, as a representative national agency, there is the Ministry of SMEs and Startups) among export support systems. The agency supports projects to export domestic companies, dispatch of trade promotion teams to small and medium-sized enterprises, overseas private network utilization projects, fostering global brands for small and medium-sized exporters, installing export incubators, supporting online exports and supporting consortia for exports of global strategic items.

Second, there is the Ministry of Trade, Industry and Energy. As a central administrative agency in charge of affairs related to industries, trade and resources in the Republic of Korea, it was launched as the Ministry of Commerce, Industry and Energy in 1948 and was reorganized as the current name in March 2013 after the Ministry 
of Commerce, Industry and Energy in 1993, Ministry of Trade, Industry and Energy in 1998 and Ministry of Knowledge Economy in 2008. From a national policy perspective, it is responsible for tasks related to trade investment, industrial technology development and foundation, balanced national development, air space, energy and resources, and provides various support through business and specialized agencies. The main export support projects are focused on trade and investment, and are in charge of supporting export insurance funds, creating a trade base, attracting foreign investment, international industrial technology cooperation, trade and investment agency support.

The Korea Trade and Investment Promotion Agency is one of the first export-related agencies. With its current headquarters at the center, it has 13 regional trade offices in Korea and 129 overseas trade offices in 84 foreign countries. Overseas market information and trade and overseas investment information obtained mainly from overseas trade agencies are provided through their respective overseas branches. Major projects related to export support include branching business, domestic and foreign exhibitions, overseas exhibitions, export consultation meetings, market development teams, overseas market research agents, overseas sales business support, government strategy business support, etc. KOTRA's specific export support system is as follows. It supports projects for overseas branching of small and medium enterprises, export consultation support projects, e-Trade overseas marketing support projects, overseas market research support projects, trade mission support projects and trade information provision.

Second, the Korea Small and Medium Venture Business Agency supports export incubators, overseas exhibitions, trade missions, export counseling sessions, overseas branching, overseas market research and overseas private network utilization projects.

Third, there is the Korea International Trade Association. The Korea International Trade Association, established in 1946, is a non-profit entity consisting of 14 domestic and 11 overseas branches outside of its local headquarters. Major export support activities include overseas promotion of export products, overseas promotion of export products, trade consulting, policy agendas, international trade cooperation, trade information provision, and training of trade experts. Similar institutions include the Korea Chamber of Commerce \& Industry and the Korea Federation of Small and Medium Business.

The financial institutions related to trade support include the Export-Import Bank of Korea, the Korea Trade Insurance Corporation and the Korea Credit Guarantee Fund. The above institutions support the role of promoting foreign economic cooperation by providing the financing needed for export and overseas investment and overseas resource development, support for foreign credit information insurance, collection and management of overseas credit information, trust guarantee system, support projects for small and medium enterprises' exchange-traded insurance premiums, and overseas non-recoverable bond recovery projects.

\subsection{Hypotheses Setting}

\subsubsection{Export Market Orientation}

Export market orientation is the concept that has applied the existing concept of market orientation to the export environment. This concept has been embodied by Cadogan, Diamondopoulos and Mortanges (1999) on the basis of the Market Orientation concept as defined in existing Kohli and Jaworski (1990), and Naver and Slater (1990) studies. They comprise three factors such as the generation of export intelligence generation, the Dissemination of export intelligence, and the responsiveness of export intelligence.

In each concept of configuration, the generation of export information represents all activities for generating information about export markets (Souchon and Diamondopoulos 1996). This means an export market survey of export companies' customers and competitors. And this export market information is obtained through exchanges between the employees of the exporting company and other departments. The spread of export information means all activities that share export information on consumers, competitors and changes in export environment in exporting countries. This dissemination of export information is made by the interaction of information between employees and other departments. Finally, the responsiveness of export information is all the factors that respond to the information obtained from the acquisition and diffusion of export information.

Export market orientation is recognized as an important resource for enterprises to achieve competitive advantage in that it is the creation of value through continuous monitoring of consumers, competitors and market environments in the export market (Cadogan et al., 2001). This enables the establishment of marketing strategies suitable to export market characteristics by effectively responding to changing market conditions and further achieving successful export performance. This export market orientation can be called as a marketing resource that 
can create a sustainable competitive advantage from the perspective of intangible resources that are entrenched in organizational culture. In particular, export market-oriented organizational actions serve as a major source of knowledge within the enterprise, which plays an important role in improving export performance through the use of information about export market environments different from domestic markets (Zahra et al., 2000).

This export market orientation also serves as a valid strategic means for small and medium enterprises in enhancing their understanding of consumers, competitors and the market environment and utilizing it for overseas management decisions (Racella et al., 2007). In order to reduce the risks posed by a market environment that is alien from the domestic market, small and medium-sized enterprises need to actively collect and utilize export market information in order to establish strategies suitable for them. The risks of uncertainty in overseas markets are high, especially for small and medium-sized enterprises, as they lack relatively tangible assets needed for export activities. Export market orientation allows small and medium enterprises to acquire and utilize export market information to reduce the risk of heterogeneity in overseas markets.

Export-market-oriented small and medium-sized enterprises can enter overseas markets more effectively by establishing a unique strategy suitable for export market conditions. Knowledge gained from export market-oriented activities serves as a major resource for small and medium enterprises in that it provides the key information necessary for export activities and increases liquidity to cope effectively with market changes (Knight \& Cavusgil, 2004). In other words, export-market-oriented SMEs will be more likely to reduce the risk of foreign market heterogeneity by making up for the deficiencies by enhancing the availability of the external trade support system as they lack the type and intangible assets required for export activities compared to large companies.

International Market Orientation is a concept similar to export market orientation. International market orientation means the extent to which an entity embodies its overseas markets. In addition, international market orientation can be defined as a new level of management thinking that provides guidance on an entity's actual activities in overseas markets, focusing on obtaining information about overseas markets (Deshpandé \& Farley, 1998).

Based on these previous studies, export market orientation is based not only on the will of the organization's CEO but also on the entire organization. Small and medium-sized companies with export market orientation are small in size and poor in the financial and manpower sectors, which will increase the incentive to use the trade support system to make inroads into overseas markets. Based on these prior studies, the following hypothesis 1 was established.

Hypothesis 1: Export market orientation will have a positive effect on the utilization of the trade support system.

\subsubsection{Learning Orientation}

In smart information society that is required to make continuous changes, learning orientation refers to acquiring and utilizing new knowledge to ensure competitiveness. Regarding the concept of learning orientation Kim (2010) defined the effort to acquire new knowledge and functions, to raise his level of competence, to achieve proficiency, and to place the results of learning on the hard worker and the tendency to continue the achievement action for a long period of time. Yoo (2012) explained that learning orientation means an important investment for survival and is how to create and use knowledge to increase competitiveness, information acquisition and sharing. Lee (2015) said that learning orientation improves understanding of job situations, improves strategic knowledge acquisition and creative behavior, thus pursuing preferences for challenging tasks, and promoting new knowledge and experience, and generally showing a positive attitude toward learning. In the Sinkula et al.(1997), elements of learning orientation were presented as learning immersion, vision sharing and openness, Calantone et al.(2002) explained learning orientation by adding inter-departmental knowledge sharing to these three concepts of learning immersion, vision sharing and openness.

Organizations also have a tendency, learning orientation, to understand the market for their organizations as they grow and accumulate experience related to their operations (Stanley and John, 1994). A strong learning orientation encourages organizational members to constantly rethink organizational norms that define market information processing activities and organizational behavior (Day, 1994). Learning orientation can lead to high-dimensional learning, which allows companies to maintain competitive advantage in the long run by providing conditions for continuous improvement of market information processing activities rather than competitors (Narver at al., 2004, Dickson, 1996). Companies with learning orientation operate overall management activities with quantitatively more information than those that do not, and the amount of information and knowledge also prevails in identifying customers' needs, showing continued and high market dominance. 
This competitive advantage also reduces the likelihood that firms will be eroded within the market. From a longterm perspective, the organizational culture of learning can keep the company competitive and is an important strategy for strengthening the corporate constitution (Dickson, 1996). In order to further enhance this learning orientation, which is recognized as an important strategy today, organizational culture and atmosphere where problems can be freely addressed are paramount (Slater \& Narver, 1995).

SMEs will have fewer opportunities to receive relatively organized work-related education or continue to learn related things. However, education and learning based on the goals and visions of these SMEs are all the more important because the smaller the size of the company, the deeper it can be perceived by its members. In particular, this means that smaller companies are more flexible and can respond quickly to changes in the external environment through proper organizational strategies such as education and learning (Carland et al. 1984).

There is no prior study that provides a clear basis for the organization's learning orientation affecting the use of trade support systems. However, based on the following findings, these studies show a multifaceted path to how learning orientation affects the use of trade support system. Learning is usually done through observation and interaction with the environment. Uncertainty in customer acceptance, rapidly changing technologies, and uncertain competitive environments recognize the need for learning, and the more companies in these environments, the more interested they are in innovation for survival.

Nonaka (1991) argued that the more an organization emphasizes learning, the more motivated its members are to learn, develop, and share new technologies and perspectives with external institutions. In addition, because the practical premise of learning organizations is the strategic will to learn new capabilities and experimental minds, continuous education, and implicitly the ability to promote innovation processes (Farrell, 1999), learning orientation is closely related to the use of knowledge from outside. Learning-oriented organizations will try to gain new skills from both inside and outside the organization and creatively solve problems that appear every minute. They will also try to have the ability and knowledge to understand and predict customer needs (Damampour, 1991). Thus, organizations that are committed in learning will have the ability to innovate and appreciate the members' ability to solve creative problems, manage uncertainty and crises.

In sum, the more learning-oriented organizations have a tendency to constantly develop through external information and policies, which is likely to increase the level of use of the trade support system. Therefore, the following assumptions were established.

Hypothesis 2: Firm s learning orientation will have a positive impact on the utilization level of trade support systems.

\subsubsection{Network Capability}

While the competitive environment will be important for firms, they should be more interested in the resources they own in terms of strategy (Das and Teng, 2000). The characteristic of this view is that companies must have resources that cannot be copied or replaced in order to continue to create competitive advantage and realize outstanding management performance, these resources can be acquired through relationships with other entities (Barney, 1991).

Studies that focus on relationships with other companies from a resource-based perspective have made significant progress (Chatterjee \& Wernerfelt, 1991; Leonard-Barton, 1992; Maijoor \& Witteloostuijn, 1996). These studies emphasize that companies can secure core resources through relationships and networks between companies. Dayer \& Singh(1998) argues that the relationship between companies can also be a source of competitive advantage as an internal resource of the entity, because the core resources of a partner company can be transferred within the partner firm through learning and alignment while building and maintaining relationships between the companies or with external institutions. Thus, building relationships with partner companies over the network can be an important channel for easy acquisition of intangible resources such as knowledge or skills that are difficult to obtain on their own, as the exchange of resources takes place beyond the boundaries of the company.(Yoon \& Kim, 2010).

The reality is that younger SMEs, such as venture firms, are relatively difficult to secure monopolistic advantages rather than those with quantitative and qualitatively abundant resources such as large and mature companies, and not many have all the relevant factors, even if they have exclusive advantages. Recognizing this, a growing number of companies that lack core competencies are seeking to create competitive advantages by establishing diverse and abundant internal and external networks and supplementing their own scarce resources. This can be said to be the purpose of establishing a network to complement special resources that can contribute to the cooperative relationships of participating companies or resources between these entities. Such an behaviors by a 
company is to use its network as a means to gain access to key resources and to strengthen competitive positioning through inter-company cooperation, as it claims from a resource-based perspective (Lavie \& Rosenkopf, 2006).

In particular, export-venture companies that want to go abroad often look for partners who can make up for their competitive weaknesses in overseas markets (Oviatt \& McDougall, 1994). And networks are important in finding opportunities, experimenting with ideas and supplementing scarce resources, reducing the risks and uncertainties arising from global management activities, making it easier to acquire knowledge and develop complementary resources (Nerkar \& Paruchuri, 2005). Therefore, building and maintaining a superior and effective network is an essential element of accelerating successful globalization (Weerawardena et al., 2007). Thus, external networks have both the utility of obtaining knowledge and information to create competitiveness in the target market for export ventures and the utility to influence the performance of companies.

Because external networks have the potential to provide tangible and intangible benefits such as new experience, resources and knowledge that a single company does not acquire, it is essential for start-ups and SMEs to continue to seek growth, and to further successfully enter and operate overseas markets. (Street \& Cameron, 2007). For example, For example, companies not long established need to acquire knowledge and information about the overseas market they are targeting, and develop products and supply channels that are suitable for consumers in those markets. However, due to the limitations of relatively small scale, limitations as a start-up company, and the constraints of resources resulting from them, it is almost impossible to carry out these activities on its own.

However, external networks provide an opportunity to overcome these weaknesses. The network for the overseas activities of start-ups has a close connection with the human network of entrepreneur or top executives. For example, if a entrepreneur had experience in a department related to the technology sector of an overseas organization prior to the start-up, it is highly likely to form an overseas human network related to technology and product development, which could be developed into the network of that company. If external networks for these activities are diverse and frequently contacted, they will actively enter overseas markets by utilizing network (Zahra et al., 2000). Therefore, it naturally becomes active in export activities, and it is highly probable that the trade support system will be actively utilized. In this context, the higher the external network capability, the more likely the trade support system will be to be utilized, setting the following hypothesis.

Hypothesis 3: External network capabilities will have a positive effect on the utilization of the trade support system.

\subsubsection{Environmental Uncertainty}

Changes in the management environment act as a change in corporate activities. How well an entity adapts to external environmental changes in a dynamic market environment, particularly in which competition and uncertainty are deepening, is perceived as a critical issue for an entity's survival. These management environments have been defined by researchers as terms that include multidimensional concepts and are varied by the purpose or approach of research. Research on the management environment divides the environment into static, dynamic, simple and complex in terms of information uncertainty, or the environment is divided into favorable and hostile environments based on the view of resource dependence, which is a rare source of resources that can be obtained through competition. This rapidly changing market environment uncertainty, instability, and degree of change are sometimes called market environment dynamics or just market dynamics.

In companies within these dynamic industries, CEOs must not only make quick strategic decisions to survive and grow in new environments, but also develop creative and innovative strategies to build rapid adaptability to cope with changing external environments (Hitt et. al., 1997). However, when the external environment is stable, the customer's preferences will be relatively fixed, and there will be no need for an increase in the costs of innovation. Although the range of external environments related to dynamic capabilities is considered to be very wide, some studies suggest that dynamic capacity is not meaningful in a stable and slow environment, and that when the environment is stable, dynamic capacity shows rather useless cost-consuming mechanisms. (Teece, 2007; O'Connor, 2008).

When demand uncertainty increases, companies must respond quickly and efficiently to changes in the consumer environment. By doing so, in an uncertain environment, companies must investigate, predict and respond quickly to consumer demand for surviving themselves. In other words, companies often use exports as new opportunities to enter markets while avoiding hostile situations where environmental uncertainties are high. That is why companies are likely to use the trade support system for the environment in overseas markets. 
In the field of international management research, the factors that constitute uncertainty in the market environment are presented such as dynamism, hostility, heterogeneity and complexity in the market environment. (Covin \& Slevin, 1989; Dess \& Beard, 1984). In order for an exporting company to continue to grow in this uncertain environment through its overseas expansion, it is necessary to accurately understand the contextual characteristics of the foreing market. This is because understanding the differences between the local market environment and the home environment and the strategic deployment of internal resources is a prerequisite for differentiating itself and gaining competitive advantage. Therefore, the use of a trade support system is a very important factor to understand uncertainties in overseas markets and to easily secure available complementary resources. In addition, the trade support system will help companies increase their overseas market performance.

Daft, Sormunent, and Parks (1988) explained that uncertainty in the external environment would increase companies' efforts to acquire information and respond to the environment. In particular, they argued that these capabilities were more important to respond quickly to customers and competitors in overseas markets. The use of trade support systems plays an important role in acquiring and utilizing customer and competitor information about export markets, and is a determinant of the exporter performance, if the customer's demands change in a tricky and technical environment is also a fluid one.

Cadogan and Diamantopoulos (1995) points out that the export market environment generates a demand for highly complex and larger information than the domestic market environment. This is because entering overseas markets requires processes and capabilities that are qualitatively different from entering the domestic market. Therefore, the greater the uncertainty in these environments, the greater the incentive for smaller or less capable companies to increase the utilization of trade support systems.

In addition, a hostile environment in the market as an external environment is an external factor that hinders corporate goals and performance. Hostility in the market environment refers to an external element that is unfriendly to an enterprise's management activities. These factors include threats to companies' normal management activities, fierce competition among their peers, competitive strength in the domestic market, and regulatory measures by the government. (Covin \& Slevin, 1989). These external pressures tend to force companies to focus on exports rather than redesigning their underlying products. Cavusgil (1984) claimed that instability in the domestic competitive environment would increase efforts to export overseas. Such increased uncertainties in the environment can naturally be expected to increase the utilization of trade support systems as companies increase interest in exports. Therefore, the following hypothesis was established.

Hypothesis 4: Environmental uncertainty (market dynamics) will have a positive effect on the use of trade support systems.

\subsubsection{Trade Support System and Export Performance}

Trade support system for SMEs is implemented to support exporting companies that have difficulty in exploring overseas markets even though they produce superior products due to poor marketing capabilities and lack of exportspecialized sales personnel. According to Kotabe and Czinkota (1992), Moini(1998) research, even small and medium-sized exporting companies in the same industry may have different export support systems that they need depending on their business characteristics, such as international experience and level of globalization. And even if they receive similar export support, there could be a difference in the effectiveness of the policy support. According to Chung and Grupp (1993) research, the effectiveness of the export support system is that the policy should be systematically and in-depth analyzed and evaluated not only from the perspective of the policy's suppliers but also from the perspective of the policy's demanders, on a comprehensive basis that covers the intended and unintended effects of the policy, the analysis of the companies to be supported, the degree to which the policy achieves the policy's goals and free-rider effects. Weaver, Berkowitz, \& Davies (1998) argued that the discussion concerning the evaluation of the effectiveness of export support policies will greatly help local organizations find ways to improve the export support system in that they should maximize the effect of the characteristics of companies that need export marketing support, namely by distributing export support resources under the implementation and implementation of appropriate support policies according to the stage of export growth.

Burpitt and Rondinelli (1998) pointed that small and medium-sized companies are faced with relatively more difficulties than large companies in entering overseas markets due to conditions, and it is necessary to recognize and utilize various export support systems to capture export opportunities. However, they pointed out that while many support programs are in place to help small and medium-sized companies advance into overseas markets, small- and 
medium-sized exporters are underutilized because of the high opportunity costs they have to endure while utilizing the support policies and their effectiveness.

Existing studies focus mostly on identifying priorities by policy or business in terms of analyzing the relationship with performance based on frequency of use of export support policies. Therefore, there are not many empirical analyses of how the use of export support policies is affecting export performance. The trend of previous studies in which export support policies affect export performance is as follows. Kjell and Lorentzen(1983) and Leoidou et al.,(1998) argues that the export support policy does not change the nature of the company, but it will lower the cost side of export activities by increasing knowledge and understanding of overseas markets, thereby increasing the efficiency of export activities. In terms of marketing resources, SMEs can receive marketing resources support for lack of funds, experience, and export know-how, which can be expected to enhance the export performance of small and medium-sized exporters.

On a practical perspective of export activities, WolKinson and Brouthers (2006) also found that small and mediumsized export companies have the biggest difficulty in their export activities, including lack of information on overseas markets, as well as export policy factors under the government's export support policy, and that they have a significant impact on export performance according to the actual use of the government's export support system such as export promotion and export infrastructure support system. Small and medium-sized exporters with low export experience will attempt to actively intervene in their export activities in establishing their initial marketing strategies. The argument that the government's export support policy should be used more actively to win market opportunities in the process is in line with Moini (1998)'s study that early export support policies are effective for exporters. Therefore, the following hypothesis was established with this logic.

Hypothesis 5: The utilization of the trade support system will have a significant positive impact on export performance

\section{Research Methodology}

\subsection{Data Collection and Analysis Methods}

The research data was collected via e-mail and faxes as a randomly selected company from the Korean trading company's address book and the Korea International Trade Association in 2017. In this study, the questionnaire was partially modified after pilot research was conducted to select and clarify survey items, and 400 copies were distributed and 230 copies were collected from February to July 2017. 223 questionnaires were used for the analysis, except those that were not useful or responding. To avoid errors in the common method bias method, the survey was conducted with a time difference between independent and dependent variables.

\subsection{Measurement of Variables}

The independent and dependent variables used in this study consist of a total of six variables. First, export market orientation was measured by four questions and learning orientation by four questions. Network capability was measured in two questions and environment uncertainty variables in four questions. The utilization of the trade support system for use as a dependent variable was measured in two questions and the performance variables were measured in five questions. The control variable is the age and size of the company. The measurement questions for each variable are as follows.

First, the measurement of export market orientation variable was measured in four questions, referring to the Cadogan et al. (2006) study. The survey items are as follows. 1) the degree to which environmental changes in export markets are regularly checked, 2) the degree to identify factors that affect the needs and preferences of overseas customers, 3) the extent to which information from overseas markets is communicated and disseminated within and outside the organization, 4) the degree of responsiveness to changes in export market conditions and trends.

Second, the measurement of learning-oriented variables was referred to the study by Sinkula et al. (1997) and Calantone et al. (2002). Learning orientation is the tendency to acquire and utilize new knowledge to secure competitiveness. To measure this, the measurement tools of Sinkula et al. (1997) and Calantone et al. (2002) were used. A total of four questions were composed of learning commitment, vision sharing and openness. 
Third, the measurement of network capability variables was referred to a study by Andersen and Keam (1998), Lee and Park (2009). Two questions include number of networks that have relations with exporters and frequency of exchanges with networks which are related to exporting companies. Fourth, the measurement of the environmental uncertainty variables consisted of four questions, referring to studies by McNaughton (2003) and Jaworski and Kohli (1993). The four questions are as follows. 1) competitive strength in the domestic market for main products, 2) prospects of the domestic market for the main products, 3) the degree of technology change in the industry to which the company belongs, 4) difficulty in predicting future technological changes in the industries in which the company belongs. Fifth, the measurement of variables in the utilization of the trade support system consisted of two questions referring to the Jung (2007) study. 1) the utilization level of export support policy, 2) the utilization level of trade financial Support policy. Finally, export performance variable was composed of five questions, referring to the study in Sausa (2004). 1) Export sales growth, 2) Export market share growth, 3) Export market share growth compared to competitors, 4) Meeting expectations, 5) Export success.

\section{Empirical Analysis}

\subsection{Reliability and Validity Verification}

The Cronbach's apha was calculated to check the internal consistency of the measured items ofeach variable. The results of the reliability analysis are described in Table 2 below. The Cronbach's apha value of all variables shows a general confidence acceptance level of 0.6 or higher, which is judged to be free from internal consistency problems.

Table 1: Varimax-Rotated Factor Analysis

\begin{tabular}{|c|c|c|c|c|c|c|c|}
\hline sing & 2 & 3 & 4 & 5 & 6 & & Cronbach's alpha \\
\hline Performance 2 & .895 & .072 & .098 & .011 & .006 & .061 & \multirow{5}{*}{0.916} \\
\hline Performance 5 & .894 & -.024 & .084 & .089 & -.028 & .037 & \\
\hline Performance 1 & .885 & .109 & .107 & .112 & .040 & -.019 & \\
\hline Performance 3 & .860 & .090 & .194 & -.111 & .041 & .008 & \\
\hline Performance 4 & .759 & .027 & .118 & .056 & -.066 & .150 & \\
\hline Uncertainty 3 & .045 & .951 & .029 & .116 & .040 & .041 & \multirow{4}{*}{0.890} \\
\hline Uncertainty 4 & .053 & .924 & .044 & .105 & -.014 & -.010 & \\
\hline Uncertainty 2 & .061 & .824 & .022 & .058 & .084 & .035 & \\
\hline Uncertainty 1 & .082 & .713 & .056 & .246 & -.170 & -.016 & \\
\hline Learning Orientation 2 & .069 & .053 & .831 & .110 & -.007 & -.015 & \multirow{4}{*}{0.848} \\
\hline Learning Orientation 3 & .164 & .019 & .830 & .030 & .075 & .008 & \\
\hline Learning Orientation 4 & .136 & .005 & .822 & .163 & .088 & .095 & \\
\hline Learning Orientation 1 & .189 & .065 & .736 & .114 & .012 & .206 & \\
\hline Market Orientation 2 & -.024 & .094 & .256 & .853 & .010 & .037 & \multirow{4}{*}{0.847} \\
\hline Market Orientation 1 & .056 & .132 & -.014 & .795 & -.011 & .159 & \\
\hline Market Orientation 3 & .055 & .039 & .388 & .772 & .064 & .070 & \\
\hline Market Orientation 4 & .064 & .271 & -.038 & .766 & .003 & .106 & \\
\hline Network 1 & .015 & .025 & .013 & .037 & .869 & .065 & \multirow[t]{2}{*}{0.793} \\
\hline Network 2 & -.031 & -.053 & .121 & -.002 & .854 & .101 & \\
\hline Support System 2 & .046 & -.054 & .111 & .166 & .034 & .836 & \multirow[t]{2}{*}{0.739} \\
\hline Support System 1 & .131 & .099 & .103 & .126 & .153 & .815 & \\
\hline Eigen Value & 3.832 & 3.096 & 2.939 & 2.765 & 1.573 & 1.503 & \\
\hline Variance $(\%)$ & 18.246 & 14.741 & 13.993 & 13.167 & 7.492 & 7.158 & \\
\hline Cumulative V (\%) & 18.246 & 32.987 & 46.980 & 60.147 & 67.639 & 74.737 & \\
\hline
\end{tabular}


A factor analysis was conducted to test the validity of each variable. The factor analysis method uses varimax rotation, principal component analysis, to extract factors based on Eigen value 1. The factor analysis showed that each parameter was properly loaded, and each item described approximately $74.73 \%$ of the total variance, showing relatively high variance explanatory power. In addition, the factor loading values of the measured items for each factor are found to be above the general acceptance criterion of 0.5 and therefore, there is no problem with the discriminant validity and convergent validity. Further, the factor analysis confirmed that the explanatory power of the first factor, which accounts for the most explanatory power, does not account for more than half of the total explanatory power, so there is no distortion due to the common method bias.

\subsection{Correlation Analysis}

Correlation analysis results are shown in Table 3 below. Because there are relatively high correlations between independent variables, there may be multicollinearity problems, this will derive variance inflation factors and review it again in the regression results.

Table 3: Pearson Correlation

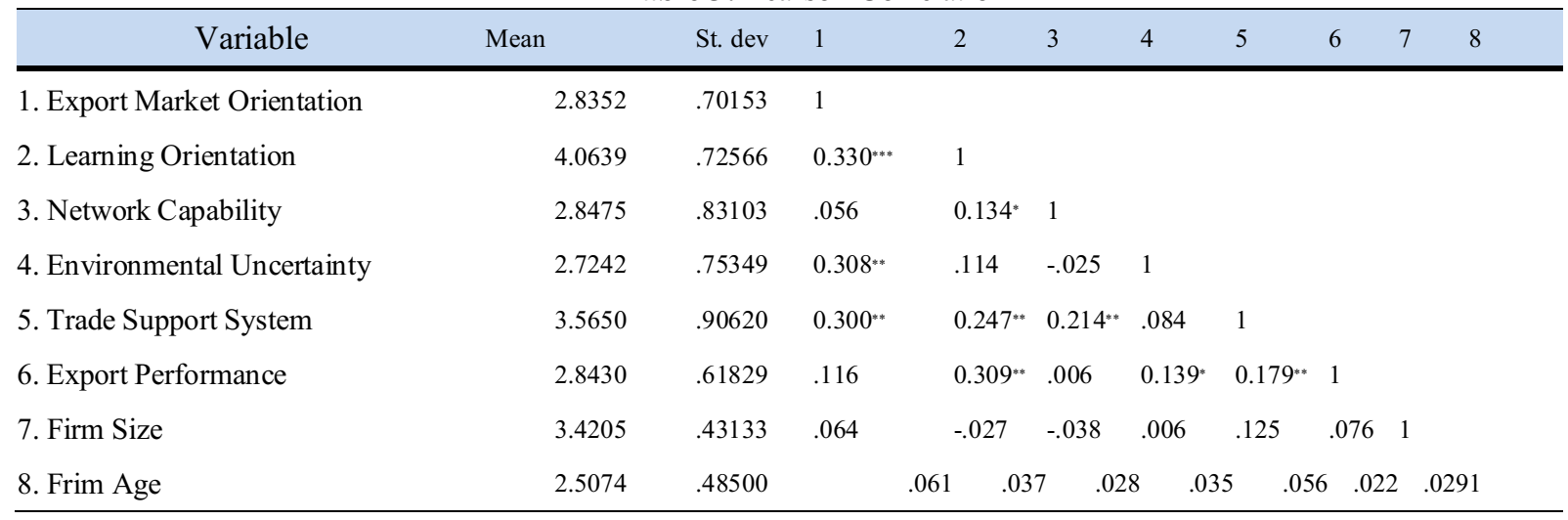

\subsection{Verification of Research Hypotheses}

\subsubsection{Basic Analysis Results}

Multiple regression analysis was carried out to analyze the determinants of the utilization of the trade support system. Multiple regression analysis consists of models 1, 2 and 3. Model 1 looked at whether the control variables, the size and age of the business, affect the utilization of the trade support system. Model 2 looked at how export market orientation and learning orientation affect the use of trade support system. Model 3 looked at how all independent variables affect the trade support system. As shown in Table 4, the Adj R2 shows a 13.9\% explanatory power in the overall model of this study and the $\mathrm{F}$ value was significant at the $1 \%$ level. The value of the Variance Inflation Factors (VIFs) represents the value from 1.009 to 1.235 and it is judged that there is no problem of multicollinearity in the regression equation of this study.

\subsubsection{Hypothesis Verification on the trade support system}

The findings will be explained with the results of Model 3, the full model. Among the control variables, it was found to have a positive effect between the size of companies and the trade support system. In other words, the larger the size of companies, the higher the utilization of the trade supports system. However, corporate age did not produce meaningful results. Hypothesis 1 expected that the higher the export market orientation, the higher the utilization of the trade support system. The analysis found that hypothesis 1 was supported $(\mathrm{t}=3.353, \mathrm{p}<0.01)$. Hypothesis 2 expected that the higher the organization's learning orientation, the higher the utilization of the trade support system. The analysis found that hypothesis 2 was supported $(\mathrm{t}=2.224, \mathrm{p}<0.05)$. Hypothesis 3 expected that the higher the organizations network capabilities, the higher the utilization of the trade support system. The analysis found that hypothesis 3 was supported $(t=2.930, p<0.01)$. Finally, hypothesis 4 expected that the higher the 
uncertainty of the environment, the more useful the trade support plan would be, but failed to produce meaningful results.

Table 4: Regression Analysis

(Dependent Variable: Utilization of Trade Support System)

\begin{tabular}{|c|c|c|c|c|c|c|c|}
\hline & & & Model 1 & & Model 2 & & Model 3 \\
\hline Variables & VIF & $\mathrm{b}$ & t-value & $\mathrm{b}$ & t-value & $\mathrm{b}$ & t-value \\
\hline \multicolumn{8}{|l|}{ Control Variable } \\
\hline Size & 1.009 & .124 & $1.850^{*}$ & .114 & $1.796^{*}$ & .121 & $1.928^{*}$ \\
\hline Age & 1.006 & .053 & .786 & .032 & .509 & .028 & .449 \\
\hline \multicolumn{8}{|l|}{ Internal Variables } \\
\hline Export Market Orientation & 1.235 & & & .234 & $3.486^{* * *}$ & .232 & $3.353^{* * *}$ \\
\hline Learning Orientation & 1.143 & & & .172 & $2.557^{* * *}$ & .148 & $2.224^{* *}$ \\
\hline \multicolumn{8}{|l|}{ External Variables } \\
\hline Network Capability & 1.023 & & & & & .185 & $2.930^{* * *}$ \\
\hline Environmental Uncertainty & 1.108 & & & & & -.001 & -.019 \\
\hline Adj. R & & & 0.009 & & 0.113 & & .139 \\
\hline F-stat. & & & 2.063 & & $8.063^{* * *}$ & & $6.973^{* * *}$ \\
\hline $\mathrm{N}$ & & & 223 & & 223 & & 223 \\
\hline
\end{tabular}

$<$ Table $5>$ is a regression analysis of how trade support system utilization affects export performance. Hypothesis 5 expected that the use of trade support systems would have a positive effect on export performance. The hypothesis 5 was supported $(\mathrm{t}=2.563, \mathrm{p}<0.05)$. Detailed analysis results for hypothesis 1 through 5 will be discussed in the conclusion.

Table 5: Regression Analysis

(Dependent Variable: Export Performance)

\begin{tabular}{|c|c|c|c|c|c|c|}
\hline & & & Mod & & \multicolumn{2}{|c|}{ Model 2} \\
\hline Variables & VIF & $\mathrm{b}$ & t-value & $b$ & \multicolumn{2}{|l|}{ t-value } \\
\hline Size & 1.016 & .075 & 1.121 & .054 & .809 & \\
\hline Age & 1.004 & .020 & .299 & .011 & .167 & \\
\hline \multicolumn{7}{|l|}{ Independent Variable } \\
\hline Utilization of E-trade & 1.019 & & & .172 & 2.563 & ** \\
\hline Adj. R & & & 0.003 & & 0.022 & \\
\hline F-stat. & & & 0.683 & & 2.353 & $* *$ \\
\hline $\mathrm{N}$ & & & 223 & & 223 & \\
\hline
\end{tabular}




\section{Discussion and Conclusion}

The Korean government and trade support agencies are making various policy and institutional efforts to ensure continued growth of small and medium-sized enterprises through the development of overseas markets. In addition, there is a growing interest in export support policies among small and medium-sized companies. In fact, various agencies related to export support for small and medium enterprises are actively implementing trade support policies. In these circumstances, the study conducted a study on which companies were actively using trade support policies. In other words, it looked at factors that affected the utilization of trade support policies and further analyzed how the utilization of trade support policies affected export performance.

First, it was shown that the export market orientation and learning orientation had a positive effect on the utilization of the trade support system. On a closer look, the higher the export orientation, the higher the use of the trade support system. These results can be seen as supporting existing research (Racella et al., 2007) in which export market orientation acts as a important strategic means to enhance consumer and competitor understanding of the market environment, and export market-oriented SMEs are more likely to reduce the risk of foreign market heterogeneity by increasing the utilization of trade support systems because they lack the tangible and intangible assets required for export activities compared to large companies. The higher the learning orientation of the organization, the higher the utilization of the trade support system. These results are empirically stating that the more learning-oriented organizations are, the more interested they are in external information and policies, the more naturally they are in use of the trade support system.

Second, analysis shows that the more diverse networks organizations establish and actively interact, the higher the level of use of the trade support system. Because external networks can provide tangible and intangible benefits such as new experiences, resources, and knowledge that a single company does not acquire, it is important for SMEs to continue to grow and, furthermore, to establish active networks to successfully enter and operate. The result is an empirical statement that such active networking and exchanges naturally increase the probability of accessing and actively utilizing the trade support system. However, hypothesis 4 that environmental uncertainty would increase the utilization of the trade support system was rejected. This is expected to be a result of increased environmental uncertainty, rather because small and medium-sized enterprises do not engage in aggressive management activities.

Finally, the more actively companies take advantage of the trade support system, the more positive it will have on export performance according to the analysis. These results are in line with a prior study that the export support policy improves efficiency of export activities by reducing the cost side of export activities by increasing the knowledge and understanding of overseas markets. (Kjell \& Lorentzen, 1983).

Although this study provides academic contributions and practical implications, it has many limitations. First of all, there will be a need to further refine on variables of trade support system. The current trade support system is underway in various areas. Therefore, the impact on companies will also vary depending on the type of trade support system. This should be considered in future research. Variables on export performance will also need to be considered more diverse. It would be nice to look at the new variables that were not covered in this study in future studies, and the moderating effects of each variable.

\section{Reference}

Andersen, O., \& Kheam, L. S. (1998). Resource-based theory and international growth strategies: an exploratory study. International Business Review, 7(2), 163-184.

Barney, J. (1991). Firm resources and sustained competitive advantage. Journal of Management, 17(1), 99-120.

Burpitt, W. J., \& Rondinelli, D. A. (1998). Export decision-making in small firms: the role of organizational learning. Journal of World Business, 33(1), 1-68.

Cadogan, J., Paul, N., Salminen, R., Puumalainen, K., \& Sunqvist, S. (2001). Key antecedents to 'export marketoriented behaviors: a cross-national empirical examination. International Journal of Research in Marketing, 18(3), 261-282.

Cadogan, J. W., \& Diamantopoulos, A. (1995). Narver and Slater, Kohli and Jaworski and the market orientation construct: integration and internationalization. Journal of Strategic Marketing, 3(1), 41-61. 
Calantone, R. J., Cavusgil, S. T., \& Zhao, Y.(2002). Learning orientation, firm Innovation capability, and firm performance. Industrial Marketing Management, 31(6), 515-524.

Carland, J. W., Hoy, F., Boulton, W. R. \& Carland, J. A. C.(1984). differentiating entrepreneurs from small business owners: a conceptualization. Academy of Management Review, 9(2), 354-359.

Cavusgil, S. Tamer (1984). Differences among exporting firms based on their degree of internationalization. Journal of Business Research, 12(2), 195-208.

Chatterjee, S., \& Wernerfelt, B. (1991). The link between resources and type of diversification: theory and evidence. Strategic Management Journal, 12 (1), pp.33-48.

Chung, S., \& Grupp, H. (1993). Technology Policy and Its Evaluation: A German Case for Small and MediumSized Enterprise and Some Implications to the Case of Korea. Korean Small Business Review, 15(1), pp.165-205.

Codogan, J. W., Diamantopoulos, A., Morgan, R. E., \& Story, V. M, (2006). Factors facilitating and impeding the development of export market-oriented behavior: A study of Hong Kong manufacturing exports. Industrial Marketing Management, 35(1), 634-647.

Codogan, J. W., Diamantopoulos, A., \& Mortanges, C. P. (1999). A measure of export market orientation: scale development and cross-cultural validation. Journal of International Business Studies, 30(4), 689-707.

Covin, J. G., \& Slevin, D. P. (1989). Strategic management of small firms in hostile and benign environments. Strategic Management Journal, 10(1), 75-87.

Covin, J. G., \& Slevin, D. P. (2010). The influence of organization structure on the utility Of an entrepreneurial top management style. Journal of Management Studies, 25(3), 217-234.

Daft, R. L., Sormunent, J., \& Parks, D. (1988). Chief executive scanning, environmental characteristics, and company performance: an empirical study. Strategic Management Journal, 9(2), 123-139.

Das, T. K., \& Teng, B. S. (2000). A resource-based theory of strategic alliances. Journal of Management, 26(1), 3161.

Day, G. S. (1994). The capabilities of market-driven organizations. Journal of Marketing, 58(4), 37-52.

Deshpandé, R., \& Farley, J. (1998). Measuring market orientation: a generalization and synthesis. Journal of Market Focused Management, 2(3), 213-232.

Dess, G. G., \& Beard, D. W. (1984). Dimensions of organizational task environments. Administrative Science Quarterly, 29(1), 52-73.

Dickson, P. R. (1996). The static and dynamic mechanics of competition: a comment on Hunt and Morgan's comparative advantage theory. Journal of Marketing, 60(4), 102-116.

Dyer, J. H., \& Singh, H. (1998). The relational view: cooperative strategy and sources of interorganizational competitive advantage. Academy of Management Review, 23(4), 660-679.

Farrell, M. A. (1999). Antecedents and consequences of a learning orientation, Marketing Bulletin, 10(1), 38-51.

Hitt, M. A., Hoskisson, R. E., \& Kim, H. (1997). International diversification: effects on innovation and firm performance in product-diversified firms. Academy of Management Journal, 40(4), 767-98.

Jaworski, B. J., \& Kohli, A. K. (1993). Market orientation: antecedents and consequences. Journal of Marketing, $57(2), 53-70$.

Jung, J. S. (2007). An empirical study on performance of export assistance programs for SMEs in Korea. Seoul, Korea: Thesis for Doctorate in Chung-Ang University.

Kim, D. C. (2010). Wine education consumer : how it impacts learning orientation, self-efficacy and satisfaction of education-training. Seoul, Korea: Thesis for Doctorate in Sejong University.

Kjell, G., \& Lorentzen, T. (1983). Exporting the impact of government export subsidies. European Journal of Marketing, 17(2), 5-12.

Knight, G., \& Cavusgil, S. (2004). Innovation, organizational capabilities, and the born-global firm. Journal of International Business Studies, 35(2), 124-141.

Kohli, A. K., \& Jaworski, B. J. (1990). Market orientation: the construct, research propositions, and managerial implications. Journal of Marketing, 54(2), 1-18.

Kotabe, M., \& Czinkota, M. (1992). State government promotion of manufacturing exports: a gap analysis. Journal of International Business Studies, 23(4), 637-658.

Lavie, D., \& Rosenkopf, L. (2006). Balancing exploration and exploitation in alliance formation. Academy of Management Journal, 49(4), 797-818.

Lee, J. H. (2015). The effects of authentic leadership of organizational commitment, task performance and creative behavior. Seoul, Korea: Thesis for Doctorate in Sungkyunkwan University.

Lee, J. H., \& Park, T. K. (2009). Born global: effects of its international orientation and network on international intensity. Journal of Entrepreneurship and Venture Studies, 12(1), 1-21. 
Leoidou, L. C., Katsikeas, C. S., \& Piercy, N. F. (1998). Indentifying managerial influences on exporting: past research and future direction. Journal of International Marketing, 6(2), 74-102.

Leonard-Barton, D. (1992). Management of technology and moose on tables. Organization Science, 3(4), 556-558.

Maijoor, S., \& Witteloostuijn, A. V. (1996). An empirical test of the resource-based theory: strategic regulation in the Dutch audit industry. Strategic Management Journal, 17(7), 549-569.

McNaughton, R. B. (2003). The number of export markets that a firm serves: process models versus the born-global phenomenon. Journal of International Entrepreneurship, 1(3), 297-311.

Moini, A. H. (1998). Small firms exporting: how effective are government export assistance programs? Journal of Small Business Management, 36(1), 1-15.

Narver, J. C., \& Slater, S. F. (1990). The effect of a market orientation on business profitability. Journal of Marketing, 54(4), 20-35.

Narver, J. C., Slater, S. F., \& Maclachlau, D. I. (2004). Responsive and proactive market orientation and new product success. Journal of Product Innovation Management, 21(5), 334-347.

Nerkar, A. and Paruchuri, S. (2005). Evolution of R\&D capabilities: the role of knowledge networks within a firm. Management Science, 51(5), 771-785.

Nonaka, J. (1991). The knowledge-creating company. Harvard Business Review, 69(6), 96-104.

O Connor, G. C. (2008). Major innovation as a dynamic capability: a system approach. Journal of Product Innovation, 25(4), 313-330.

Oviatt, B. M., \& McDougall, P. P. (1994). Toward a theory of international new ventures. Journal of International Business Studies, 25(1), 45-64.

Racela, O., Chaikittishilpa, C., \& Thourmrungroje, A. (2007). Market orientation, international business relationships and perceived export performance. International Marketing Review, 24(2), 144-163.

Sousa, C. M. (2004). Export performance measurement: An evaluation of the empirical research in the literature. Academy of Marketing Science Review, 4(9), 1-24.

Sinkula, J. M., Baker, W. E., \& Noordewier, T. (1997). A framework for market-based organizational learning: linking values, knowledge, and behavior. Journal of the Academy of Marketing Science, 25(4), 305-318.

Slater, S. F. \& Narver, J. C. (1995). Market orientation and the learning organization. Journal of Marketing, 59(3), 63-74.

Souchon, A. L., \& Diamantopoulos, A. (1996). A conceptual framework of export market information use: key issues and research propositions. Journal of International Marketing, 8(3), 36-60.

Stanley F. N., \& John, C. N. (1994). Does competitive environment moderate the market orientation-performance relationship? Journal of Marketing, 58(1), 46-55.

Street, C. T., \& Cameron, A. (2007). External relationship and the small business : a review of small business alliance and network research. Journal of Small Business Management, 45(2), 239-266.

Teece, D. J.(2007). Explicating dynamic capabilities: the nature and micro foundations of (sustainable) enterprise performance. Strategic Management Journal, 28(13), 1319-1350.

Weaver, K. M., Berkowitz, D., \& Davies, L. (1998). Increasing the efficiency of national export development programs: the case of Norwegian exporters. Journal of Small Business Management, 36(4), 1-11.

Weerawardena, J., Mort, G. S., Liesch, P. W., \& Knight, G. (2007). Conceptualizing accelerated internationalization in the born global firm: a dynamic capabilities perspective. Journal of World Business, 42 (3), 294-306.

Wolkinson, T. J., \& Brouthers, L. E. (2006). Trade promotion and SME export performance. International Business Review, 15(3), 233 252.

Yoo, B. H. (2012). An effect of learning orientation on firm performance: focusing on customer orientation and innovativeness. Korean Journal of Business Administration, 25(6), 2809-2826.

Yoo, S. J. (2010). A study on the measures for export promotion of small and medium enterprise in Korea. International Commerce and Information Review, 12(4), 193-211.

Yoon, G. C., \& Kim, M. H. (2010). A study on mediating effect of international marketing activity between R\&D and network capabilities and performance of Korean INNOBIZs. International Area Studies Review, 14(2), 181204.

Zahra, S. A., Ireland, R. D., \& Hitt, M. A. (2000). International expansion by new venture firms: International diversity, mode of market entry, technological learning, and performance. Academy of Management Journal, 43(5), 925-950. 